\title{
2 Overall layout and possible reasons for its change in manuscript
}

In most Indic manuscripts each folio contains several elements: one or more texts, blank margins, string-holes, symbols, 'gaps' and 'blank spaces'. ${ }^{101}$ The elements distribution on the folio is in relation to one another and can be termed a layout, or mise en page. Here the script size, line numbering and justification are elements that are part of the layout. Several factors determined the layout of a manuscript, for instance the shape of the writing supports, scribal practice, and text style (i.e. whether or not the text is composed in verse or prose) etc.

This chapter's main objective is to investigate the various layout elements in the manuscripts selected for the study to highlight the similarities and differences characterising the layout of manuscripts according to the place of their production. At times it may offer the opportunity to gain more precise information on the period of production of the manuscripts within the time-frame of the $9^{\text {th }}$ to $13^{\text {th }} \mathrm{c}$. relevant to this study.

\subsection{Writing support}

The arrangement of texts, free spaces, etc. on a folio is closely related to the writing support on which the manuscript has been made. In this instance palmleaf manuscripts have largely been used, all of which are in pothi format. ${ }^{102}$ This means their length is longer than their breadth. The leaf shape has been adopted for writing, and the text often runs horizontally on each folio. ${ }^{103}$

According to its length, each folio can have one or two string-holes. A short leaf will usually have just one string-hole (see sections 2.4.1-2.4.3 for examples of layout below). Long leaves, usually have two string-holes (see sections 2.4.12.4.3 for examples below). ${ }^{104}$

101 In this work a small free space, used between smaller text units (such as sentences, pādas or first and second halves of the ślokas) on the folio, has been categorised as a 'gap' (see section 4.2 for more details below). The free spaces left at the end of a (sub-)chapter, text demarcated by a set(s) of double danḍas have been categorised as a 'blank space' (see section 4.1 for more detail below).

102 For pothī, see Formigatti 2011, 29.

103 On the discussion of the direction of writing, see Hoernle 1900, 131.

104 See Godakumbura 1980, IL in which the rule for fixing of the holes on the folio has been given (though some readings in the verse appear to contain errors; I have marked them with a 
The text may run all along the length of the folio or may be divided into two or three text-sections. ${ }^{105}$ In the latter, portions of the folio page are left clear intentionally, with no written text. These portions may occupy the entire space above and below the string-holes, or just a small area of the space around the string-holes (this smaller free space may take a kind of a 'square shape').

Furthermore, even in one manuscript, the shape of the leaves may vary considerably. ${ }^{106}$ Some leaves may to an extent be regular and some appear slightly curved or taper on the left and right margins (e.g. see Figs. 2.4.1-II, 2.4.1III, 2.4.1-V, 2.4.3-III, 2.4.3-VI, 2.4.3-VII below). ${ }^{107}$ In such cases, scribes break the lines where they cannot write properly and insert space-fillers. ${ }^{108}$ This results in widely different numbers of akșaras per line, even on the same folio.

\subsection{Scribal practice}

Another important part of this study is the scribal practice, which may be directly related to the arrangement of the text and other features in manuscripts. If more than one scribe had been involved in the production of a manuscript, certain features may be perceived (e.g. script, overall layout etc.) as altered within the same manuscript. In such cases, one scribe may write the text carefully for his lines appear as straight, whereas another scribe may write in a less sophisticated way or not take the same pains to produce clear or regular writing, resulting in writing that appears to be of poor quality.

Regarding symbols, one scribe may draw them beautifully, but another may draw extremely simple ones, with little effort (even in the same manuscript). In other cases, the scribe may not draw symbols and leave blank spaces in their place (see section 4.1 below).

sic sign) as follows: ayamena(!) caturbhāgaṃ tribhāgaṃ punar eva ca[|]ubhayoḥ sūtramadhyena tathā kuryāc chidralakșaṇaṃ(!)||; on the topic, see also Losty 1982, 7.

105 If the text lines are left clear from top to bottom on the string-hole space on the folio making the organisation of the text on the folio appear like a kind of column, it is categorised as a 'text-section' in the present study (see section 2.5 for more details below).

106 Regarding study of the writing support, especially palm-leaves and size, see Hoernle 1900. 107 See Thaker 2002, 143.

108 Space-fillers are normally found at the beginning or end of lines on the left or right side on the folio. Here scribes cannot write properly due to the format of leaf and thus place such symbols in order to indicate that a line or portion of text continues in another line of the same folio or in another folio. See Einicke 2009, 487 for the term 'Zeilenfüller'. 
However, a scribe may write the text in three text-sections on a folio featuring two string-holes, while another may write the text in the same manuscript in only two text-sections in spite of the two string-holes (e.g. see section 3.9.3 below).

Also, a scribe may clearly divide smaller text units, such as pādas or the first and second halves of ślokas, ${ }^{109}$ leaving small but visible gaps between those parts of the text. In the same manuscript, however, another scribe may exhibit no interest in demarcating such kinds of text divisions (see sections 3.9.1 and 3.9.2 below).

\subsection{Text style}

The text style contained in a manuscript may be closely related to its layout. If the text is in verse, a scribe may write the text in to mirror the metrical scansion. Scribes may therefore leave small gaps either between the pādas ('quarters') or only between the first and second half of the verse (see sections 4.2.1 and 4.2.2 below).

This phenomenon can be related to the level of each scribe's proficiency. We know that not all scribes were of the same level, ${ }^{110}$ and that learned scribes were expected to have mastery in metrics. ${ }^{111}$ Furthermore, it could well be that this way of dividing texts may be the result of the practice of writing under dictation.

\subsection{Time and place of manuscript production}

Certain layout features are clearly determined by the temporal and spatial setting of their production. The lines are written more regularly and the text is arranged carefully on the folio. In the corpus considered here, one sees that from the $10^{\text {th }}$ c. onward the layout becomes gradually standardised. ${ }^{112}$

Furthermore, the site of manuscript production also bears a close relation to the text arrangement. A particular type of writing style, the overall page layout,

109 A śloka or anuștubh (metre) contains total 32 syllables, each quarter consisting of eight syllables e.g. see Apte 1957, Appendix, 3. See also Steiner 1996 for a detailed study on anușțubh metre.

110 For the qualifications and types of scribes, see Sarma 1992, 33-40. On scribes, see also Einicke 2009, 430-446; De Simini 2016, 96-102.

111 See Sarma 1992, 32-33: chandolakșaṇatattvajñam satkaviṃ madhurasvaram | praṇașțam smarati grantham śreștham pustakalekhakam(!) \|. We may at least deduce from this that a scribe was expected to know the metres and be a good poet.

112 I am not claiming here that this applies to all existing manuscripts for the regions. Exceptions and variations are always to be found. 
or perhaps just a few features may have been developed and used solely in a specific area.

In the following, I will outline the overall layout of each manuscript from the three groups implemented in my analysis. I present the manuscripts in their possible chronological order, and specify the features that relate them to the regions of manuscript production.

\subsubsection{Examples of layout in Nepalese manuscripts}

The group of Nepalese manuscripts selected for this study consists largely of 22 manuscripts exhibiting a variety of layouts that were to become increasingly standardised within the period $9^{\text {th }}$ to $13^{\text {th }} \mathrm{c}$.

\section{$\mathbf{S P}_{\mathbf{1}}$}

$\mathrm{SP}_{1}$ contains two string-holes per folio, each containing five to eight lines. The sample numbers of akșaras per line are 96 (158v4, 159v2, 159v5, 186v4) (regarding the organisation of the ślokas by gaps in each text-section on the folio), 101 (10b3) and 99 (10b4) (without the division of ślokas by means of gaps). Not all folios are of the same size or shape: some taper at the edges and others are slightly curved. The text has been divided into three text-sections on each folio. On some folios, within each text-section, the first and second half of each sloka is further separated by a small gap (see sections 3.9.1 and 4.2.2 for more details below). If the pādas are arranged within the frame of text-sections accordingly, each folio line contains three ślokas. With a few exceptions, at least two scribes appear to have worked on the production of the manuscript. ${ }^{113}$ The overall layout of the manuscript can be seen as follows.

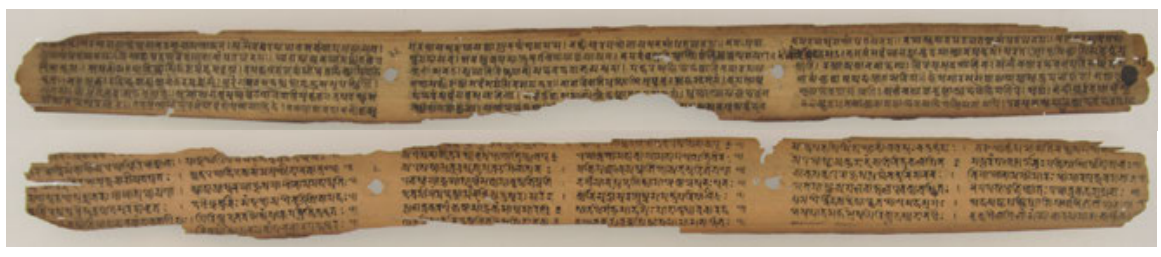

Fig. 2.4.1-I: Overall layout, fols.? (NAK image 71a, 74a) @ NAK

113 This issue has been discussed thoroughly in section 3.9.1. 


\section{PT}

PT has two string-holes per folio, each with three, five or seven lines. The sample numbers of akșaras per line are 60 (14v4), 69 (17r3). The text has been divided into two or three text-sections (two text-sections on 22v, 35r, 37rv, 44rv, 46r, 47rv-51rv, 52r, 53r, 54rv-57rv etc. and three text-sections on 1v, 2r, 3rv, 4rv, 5v, 6rv, 7rv, 8rv, $9 \mathrm{v}, 10 \mathrm{rv}-14 \mathrm{rv}, 16 \mathrm{rv}-21 \mathrm{rv}, 22 \mathrm{r}, 23 \mathrm{rv}-34 \mathrm{rv}, 35 \mathrm{v}, 36 \mathrm{rv}, 39 \mathrm{rv}, 40 \mathrm{rv}-43 \mathrm{rv}, 52 \mathrm{v}, 53 \mathrm{v}$, 62rv). The leaves are not of a uniform size (as can be seen in Fig. 2.4.1-II). Some of the folios taper at the edges and some folios are considerably curved. In many cases, this leads to irregularity of line-length, the number of lines per folio, and the number of akșaras on the folio. A narrow, empty space has been left on the margins (concerning precise measurements of the script, text-sections, etc., see the Cambridge online catalogue entry). The overall layout of the manuscript can be seen in Fig. 2.4.1-II.

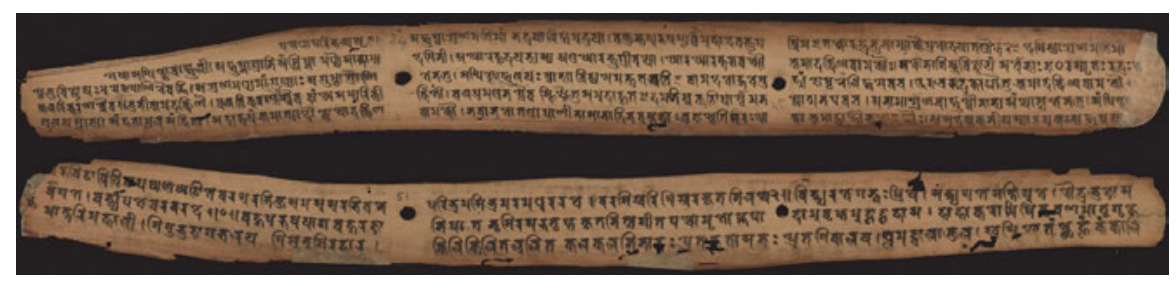

Fig. 2.4.1-II: Overall layout, fols. 34v, 51v @ CUL

\section{SS/N}

$\mathrm{SS} / \mathrm{N}$ has two string-holes per folio, each with seven to eight lines. The sample numbers of akșaras per line are 88 (23v1), 110 (23v7), 98 (114v4). The text has been divided into three text-sections on each folio. ${ }^{114}$ Folios are not of uniform size or shape. Some folios taper at the edges and a few others are slightly curved (e.g. Fig. 2.4.1-III). Small gaps have been used between the first and second halves of the ślokas or between 'sentences' on many folios (see section 4.2.1.2 below). Taking palaeography, symbol and space-filler, into account it may be assumed likely that four to five scribes could have worked on the manuscript's production. The overall layout in the manuscript may be seen as follows.

114 One should note that there are five folios on which the titles of the (sub-)chapters are written in the column structure. Two different hands are clearly evident on these folios. In comparison to the hands of the main text on other folios both hands on these folios look rather modern. 


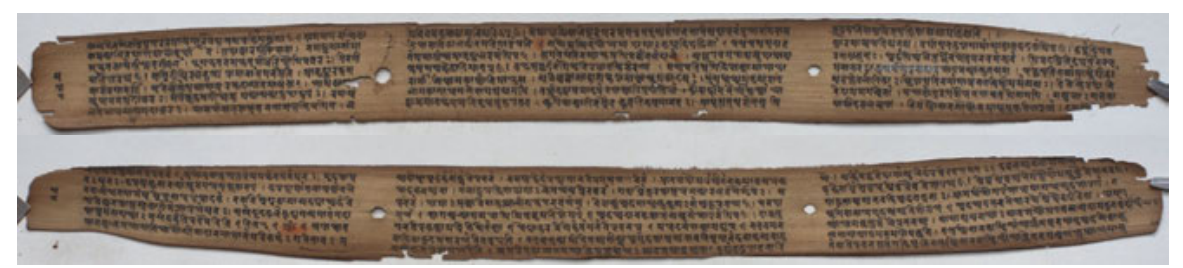

Fig. 2.4.1-III: Overall layout, fols. $119 \mathrm{v}, 130 \mathrm{v}$ (C KL

\section{$\mathrm{SP}_{2}$}

$\mathrm{SP}_{2}$ presents two string-holes per folio, each containing four to seven lines per folio. The sample numbers of akșaras per line are 96 (5a3), 95 (5a5), 94 (204a4). The text has been divided into three text-sections on each folio. ${ }^{115}$ Some folios taper at the edges. On one folio ślokas have been divided precisely by small gaps within each text-section. At least two scribes may have worked on the manuscript production. ${ }^{116}$ Two folios exemplifying the overall layout in the manuscript can be seen in Fig. 2.4.1-IV.

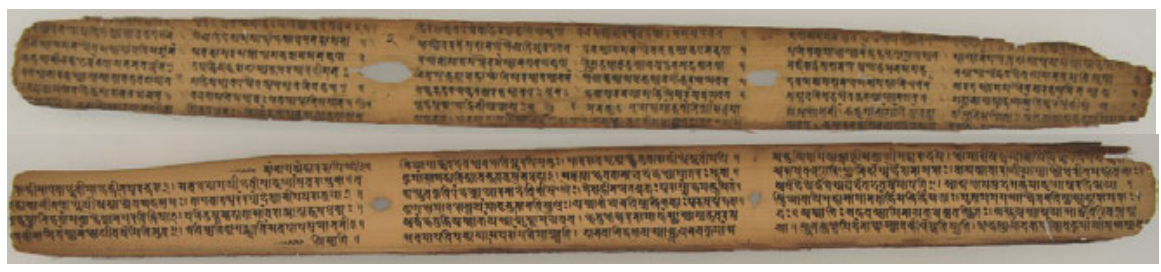

Fig. 2.4.1-IV: Overall layout, fols.? (NAK image 5a, 203a) @ NAK

\section{NTS}

NTS has two string-holes per folio, each with five or six lines. The sample numbers of akșaras per line are 97 (90v3), 99 (101v3), 106 (105r5) akșaras. The text

115 On '1rv' the figure-numbers have been arranged in columns located between vertical lines. After most of these numbers there is no writing. However, a few of these numbers contain the titles of the chapters. It is likely the numbers without any writing were to have featured the titles. In comparison with hands of other folios, the hand on this folio looks rather modern. This might have been added comparatively later.

116 This has been discussed in detail in section 3.9.2 below. 
has been divided into three text-sections on each folio. Some of the folios taper at the edges. Small gaps have been used between pādas of the ślokas on some folios (see section 4.2.1.1 for more detail below). The overall layout in the manuscript can be seen as follows.

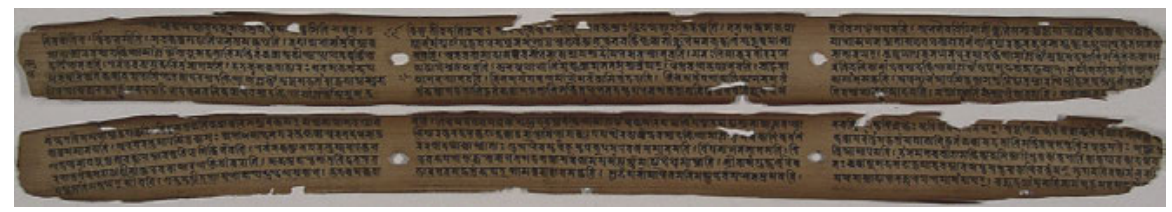

Fig. 2.4.1-V: Overall layout, fols. 99v, 100r (C NAK

\section{KT}

KT presents two string-holes per folio, each containing five to seven lines per folio. The sample numbers of akșaras per line are 47 (13v3), 61 (49v4), 58 (91v5). The text has been divided into two or three text-sections. At least three scribes may have worked on the production of the manuscript, evidenced by the layout and other features such as symbols and palaeography. ${ }^{117}$ Examples of the overall layout in the manuscript can be seen as follows.

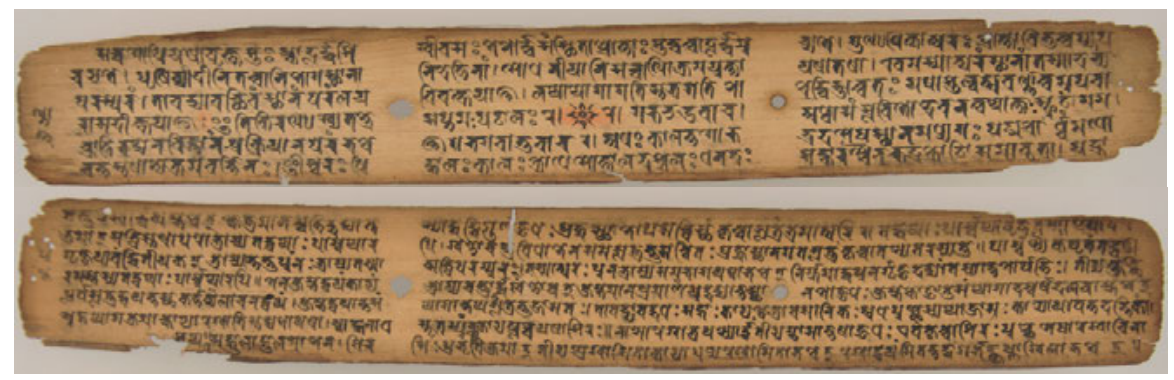

Fig. 2.4.1-VI: Overall layout, fols. 13v, 44v @ NAK

117 This topic has been discussed in detail in section 3.9.3 below. 


\section{KV/UVDh}

KV/UVDh contains two string-holes per folio, each with six lines. The sample numbers of akșaras per line are 76 (4v1), 84 (54r1). Some folios taper at the edges. Symbols appear around the string-holes on the folio. The text has been divided into three text-sections on each folio, aside from $1 \mathrm{v}$ which is purported to have been added later (according to the palaeographical evidence) and on 55r where the text has been divided into only two text-sections. On $1 \mathrm{v}$ the uppermost and lowermost lines run across the whole folio. The writing here has faded considerably. On 55r, the two uppermost and two lowermost lines run across the right string-hole space and the left string-hole space is left clear of the text. A set of two parallel vertical ruling lines have been drawn after the left text-section, before and after the central text-section on 13r, in the outer part before the left text-section and after the right text-section on $17 \mathrm{v}$. The overall layout in the manuscript can be seen as follows.

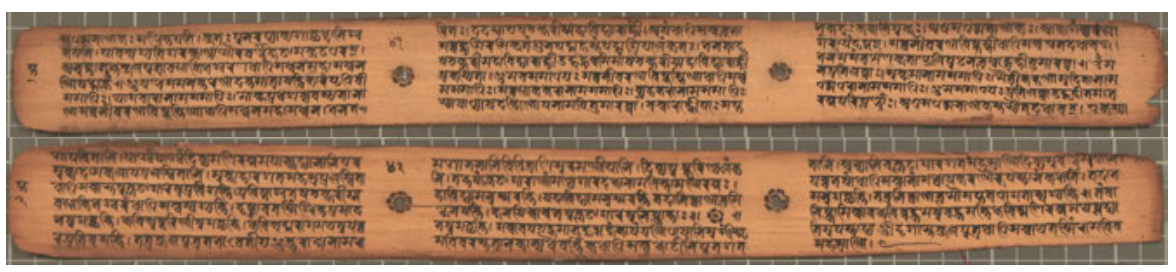

Fig. 2.4.1-VII: Overall layout, fols. 41v, 42v @ NAK

$\mathrm{SP}_{3}$

$\mathrm{SP}_{3}$ has two string-holes per folio, each of five or six lines. The sample numbers of akșaras per line are 108 (34r1), 98 (184v1), 100 (130v6). The text has been divided into three text-sections on each folio. Examples of the overall layout in the manuscript can be seen in Fig. 2.4.1-VIII. This and the following manuscript have been discussed in detail in section 3.8.2 below.

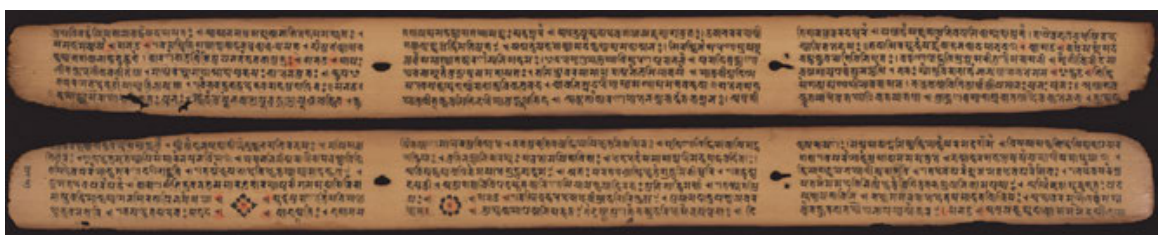

Fig. 2.4.1-VIII: Overall layout, fols. 46v, 48r @ Bodleian Library, Oxford 
$\mathrm{SP}_{4}$

$\mathrm{SP}_{4}$ presents two string-holes per folio, each containing five (on 250rv, 71rv, 254rv, 253rv, 248rv, 251rv, 249rv, 61rv, 256rv, 247rv) or six lines (on 63rv, 62rv, 10rv, 9rv, 5rv, 65rv, 68rv, 67rv, 66rv, 6rv, 230rv) lines per folio. The text has been divided into three text-sections. The overall layout in the manuscript can be seen as follows.

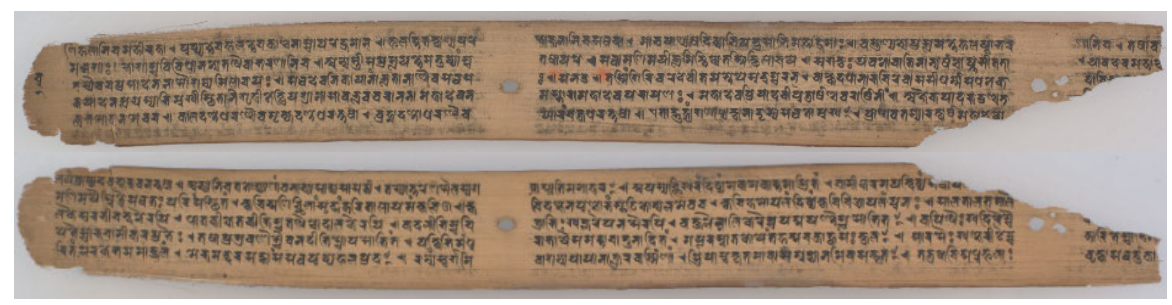

Fig. 2.4.1-IX: Overall layout fols. 61rv @ NAK

\section{YY}

YY has two string-holes per folio (except for the very last small folio which only has one string-hole), each with six or seven lines. The sample numbers of akșaras per line are 59 (5r1), 53 (4v1). The text has been divided into two textsections on each folio. The space above and below the left string-hole has been left clear of text, however, the lines on the right string-hole space have not been left clear above and below the string-hole. The left text-section is considerably narrower than the right text-section. The overall layout in the manuscript can be seen as follows.

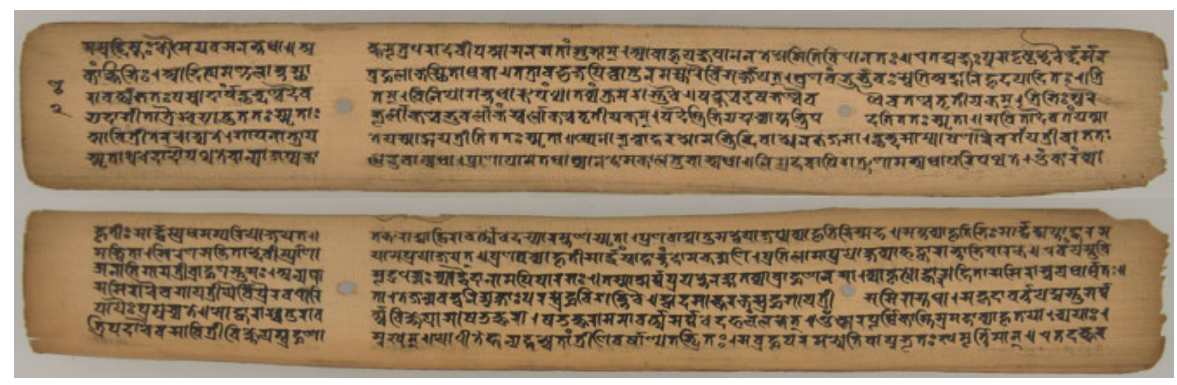

Fig. 2.4.1-X: Overall layout, fols. 12v, 13r @ NAK 
$\mathrm{HV}_{1}$

$\mathrm{HV}_{1}$ presents two string-holes per folio, each containing four or five lines per folio. The sample numbers of akșaras per line are 96 (14v1-5), 93 (160r1), 88 (160r2), 104 (160r3), 95 (160r4), 96 (160r5). The text has been divided into three text-sections on each folio. The leaves are even and written in a regular way. Furthermore, the first and second halves of most of the ślokas on most of the folios have been divided by gaps in text-sections. Only on very few folios is the text not divided by any gaps. If the pādas are organised within the frame of textsections accordingly, mostly three ślokas appear per line (see section 4.2.2.3 for more detail below). Examples of the overall layout in the manuscript can be seen as follows.

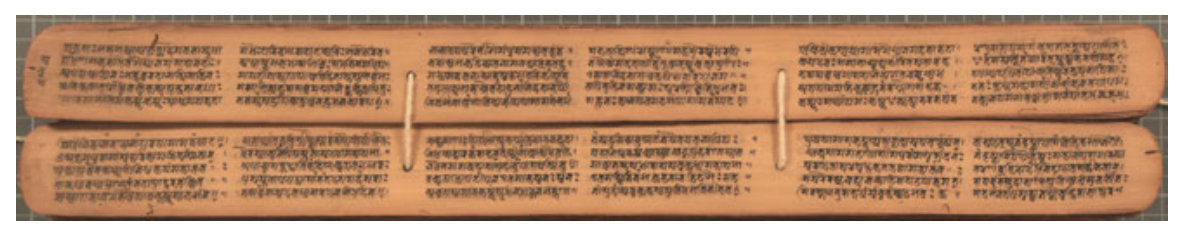

Fig. 2.4.1-XI: Overall layout, fols. 169v, 170r @ NAK

\section{HY}

HY has one string-hole per folio, each with three to six lines. The sample numbers of akșaras per line are 57 (15v3), 59 (16r1). The folios do not have uniform size. Some of the folios taper at the edges and some folios are slightly curved (e.g. Fig. 2.4.1-XII).

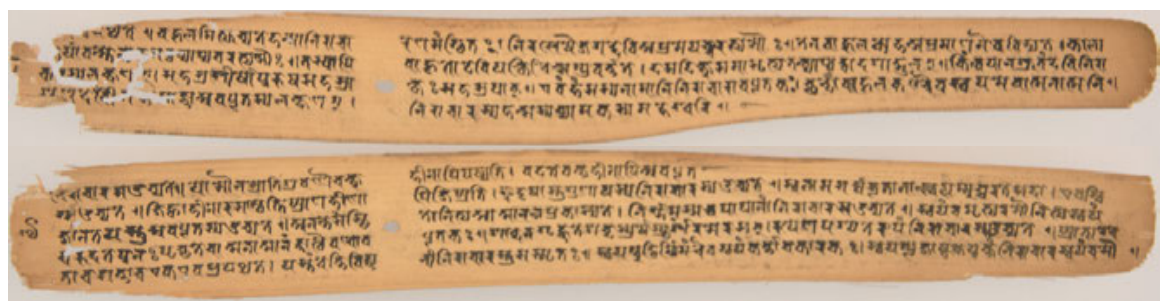

Fig. 2.4.1-XII: Overall layout, fols. 6v, 7v @ NAK 
The string-hole appears almost one third away from the left edge on the folio. The text has been divided into two text-sections on each folio. Lines are left clear from top to bottom on the string-hole space. The left text-section is considerably narrower than the right text-section. Examples of the overall layout in the manuscript can be seen in Fig. 2.4.1-XII.

\section{DDh}

DDh presents two string-holes per folio, each with four to five lines. The sample numbers of akșaras per line are 73 (2v1), 78 (32v1), 74 (26r5). The text has been divided into three text-sections. The leaves are even and the lines are regular. Examples of the overall layout in the manuscript can be seen as follows.

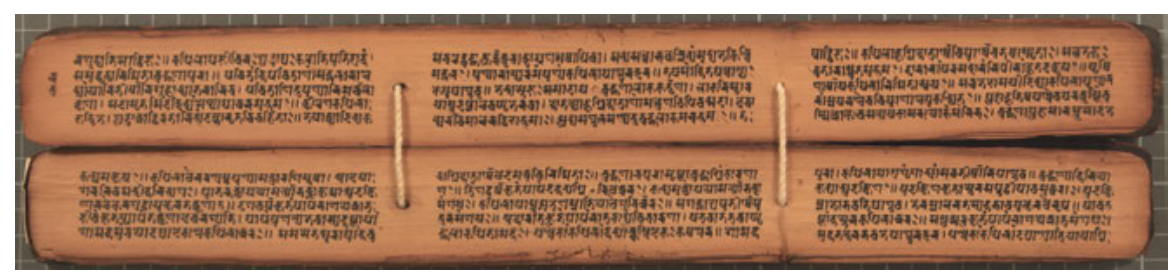

Fig. 2.4.1-XI: Overall layout, fols. 36v, 37r @ NAK

$\mathrm{TS}_{1}$

$\mathrm{TS}_{1}$ has two string-holes per folio, each with six lines. The sample numbers of akșaras per line are 110 (4r1), 107 (10v4), 105 (55v6). The text has been divided into three text-sections on each folio. Leaves are even and lines appear regular. The overall layout in the manuscript can be seen in Fig. 2.4.1-XIV.

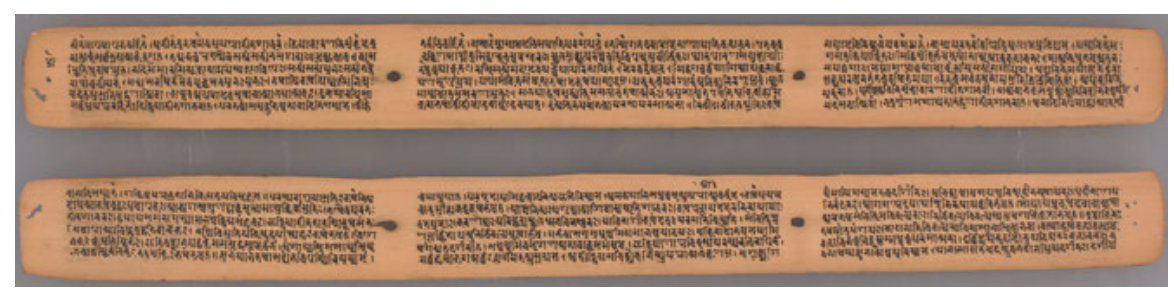

Fig. 2.4.1-XIV: Overall layout, fols. 10v, 11r @ NAK 


\section{VDh}

VDh contains two string-holes per folio, each mostly with five lines (except for four lines on 16r, 49v, 59rv, 89v, 160v). The sample numbers of akșaras per line are 91 (28v1; with ruling-lines), 89 (60v2; with square-shaped string-hole space). Lines are left clear top to bottom on both string-hole spaces on some folios and the text appears divided into three text-sections on e.g. 2rv-24rv, 26rv-32rv, 33r, 34rv-38rv, 39r, 40rv-48rv, 49r, 50rv-52rv. Furthermore, there are no textsections on e.g. $1 \mathrm{v}, 25 \mathrm{rv}, 33 \mathrm{v}, 39 \mathrm{v}, 49 \mathrm{v}, 53 \mathrm{rv}-160 \mathrm{r}$, only a square-shaped free space has been left around both string-holes. Some of the folios (on e.g. 2r-24rv, 26rv-30rv) contain vertical ruling-lines and delimit text-sections. However, on most of the folios $(1 \mathrm{v}, 25 \mathrm{rv}, 31 \mathrm{r}-160 \mathrm{r})$ there are no ruling-lines. Examples of the overall layout in the manuscript can be seen as follows.

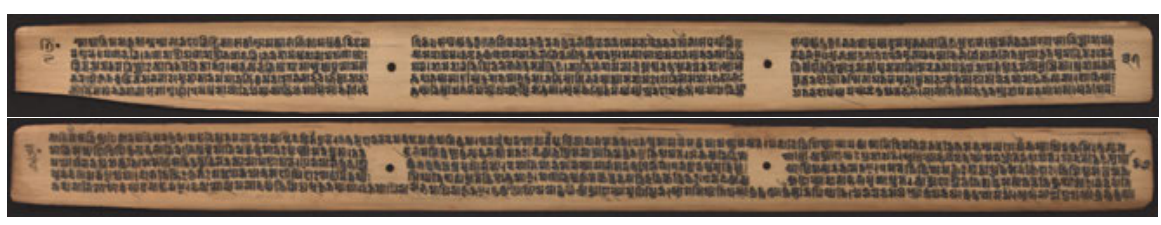

Fig. 2.4.1-XV: Overall layout, fols. 37v, 52v (C) NAK

\section{SSS}

SSS has two string-holes per folio, each with six lines (except five lines on 1v, 2rv, 3r, 4v). The sample numbers of akșaras per line are 92 (2v1), 86 (34r6), 84 (53v1). The text has been divided into three text-sections on each folio (except on $54 \mathrm{r}$ on which lines run around the string-holes on the folio. On palaeographical grounds it seems that which is written from mid way of the second line text may be of a different hand). ${ }^{118}$ The leaves are even and lines appear rather regular. Here is an example of the overall layout in the manuscript:

118 N.B. on fol. $1 \mathrm{r}$ a list of chapters written in modern hand and arranged in seven columns has been added later. 


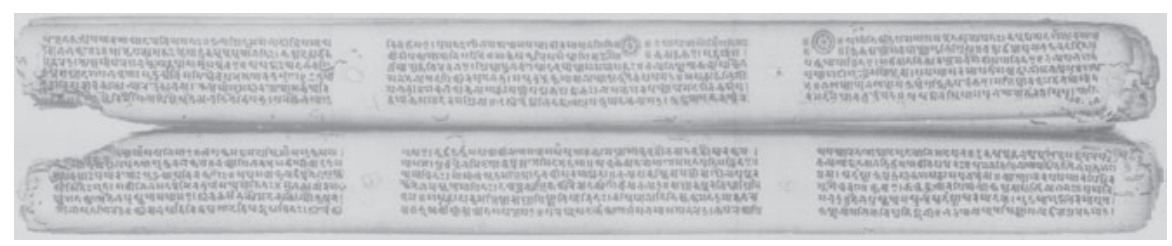

Fig. 2.4.1-XVI: Overall layout, fols. 33v, 34r @ NAK

\section{AṣP1}

AșP $\mathrm{P}_{1}$ presents two string-holes per folio, each with mostly five (except for 6 lines on 197v, 204r, 206v, 226v, 237rv, 277v and 4 lines on the last folio 282v). Leaves are even and lines appear regular. The sample numbers of aksaras per line are 94 (3v1), 107 (66v1), 104 (204v5). The text has been divided mainly into three text-sections (except on some folios where the first line runs across the right string-hole space on 46r, $136 \mathrm{r}, 204 \mathrm{v}, 237 \mathrm{v}, 238 \mathrm{v}, 268 \mathrm{r}, 281 \mathrm{r}$, the last line across the string-hole space on 203v and both first and last lines across the right string-hole space on 66v, 233v, 201r, 204r). Examples of the overall layout in the manuscript can be seen in Fig. 2.4.1XVII.

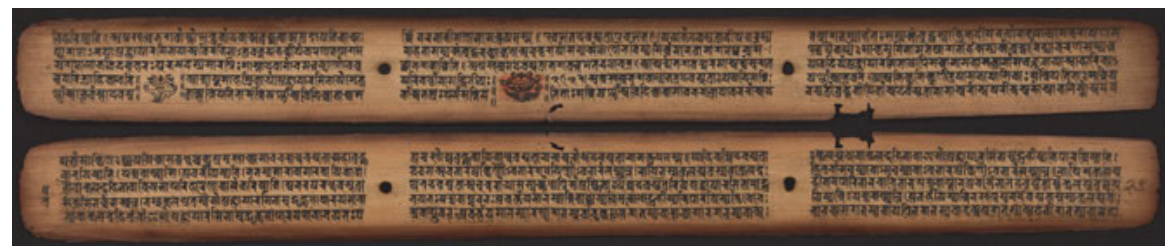

Fig. 2.4.1-XVII: Overall layout, fol. 26rv @ NAK

$\mathrm{HV}_{2}$

$\mathrm{HV}_{2}$ contains two string-holes per folio, each with five lines (except six lines on 1v, 2rv). The sample numbers of akșaras per line are 106 (3v1), 104 (90v1), 92 (100v5). The text has been divided into three text-sections on all folios (except on 416rv on which first line runs across the right string-hole space). The leaves are even and the lines are written in a regular form. The overall layout in the manuscript can be seen in Fig. 2.4.1-XVIII. 


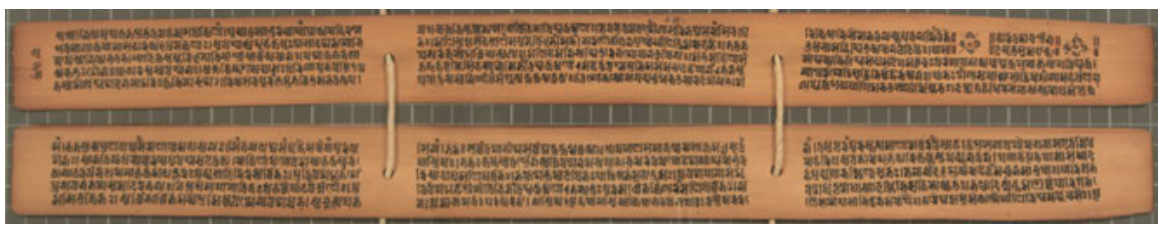

Fig. 2.4.1-XVIII: Overall layout, fols. 189v, 190r @ NAK

\section{SDhPS}

SDhPS presents two string-holes per folio, each with six lines (except on 21r, $25 \mathrm{v}, 26 \mathrm{r}, 34 \mathrm{r}, 120 \mathrm{v}$ on which five lines can be found). The sample numbers of akșaras per line are 122 (35v1), 106 (74v6), 94 (127v2). The text has been divided frequently into three text-sections (except on $9 \mathrm{v}, 133 \mathrm{v}$ on which text appears divided only into two text-sections). Leaves are to a great extent of uniform size and the lines are of regular form. On 138v, 139rv ruling-lines can be found and they delimit text-sections. Small gaps can be found between smaller text units such as the sentences on 125r-128r, 131r-132r. The overall layout in the manuscript can be seen in Fig. 2.4.1-XIX.

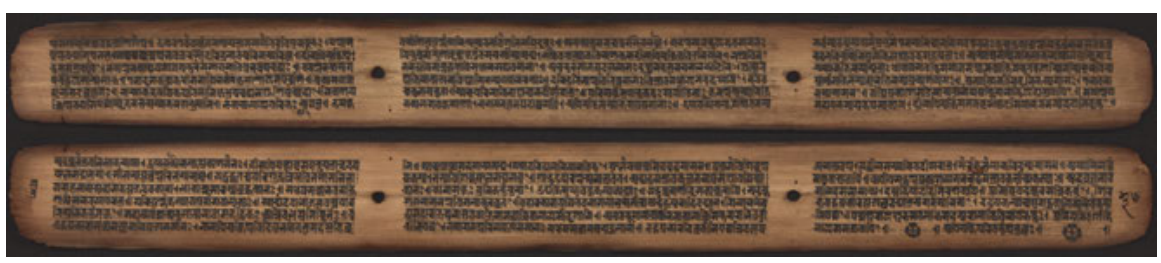

Fig. 2.4.1-XIX: Overall layout, fol. 36rv @ NAK

$\mathrm{Aṣp}_{2}$

Aș $\mathrm{P}_{2}$ has two string-holes per folio, each with mostly six lines (except seven lines on 69r, 177r and 179r). The sample numbers of akșaras per line are 110 (60r1), 98 (60v3). The text has been divided largely into three text-sections (except on 60rv where the text has not been divided into text-sections; the uppermost and lowermost lines run across the whole folio, on 166r on which text appears divided only into two text-sections). The leaves are even and the lines appear regular. Below is the overall layout of the manuscript: 


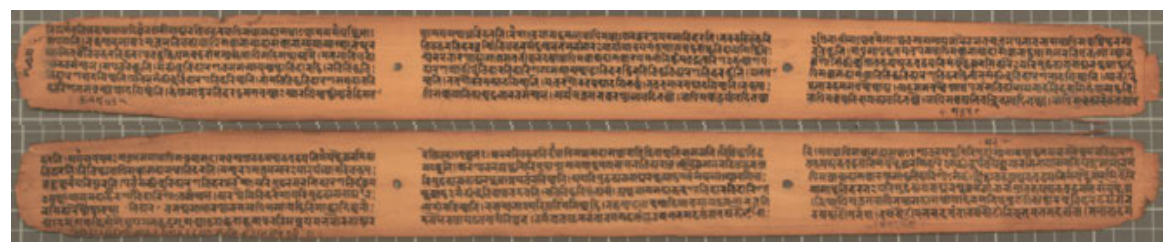

Fig. 2.4.1-XX: Overall layout, fols. 60v, 62r @ NAK

\section{SS}

SS presents two string-holes per folio, each with six to seven lines. The sample numbers of akșaras per line are 80 (1v1), 58 (37r5). The text has not been divided into text-sections on the folio. Square-shaped free space has been left around the left and right string-holes on each folio and on both sides the square-shaped free space is an area of five text-lines in height on the folio. The uppermost and lowermost lines run across the whole folio. On some folios the text is written in cursive style. The overall layout of the manuscript can be seen in Fig. 2.4.1-XXI.

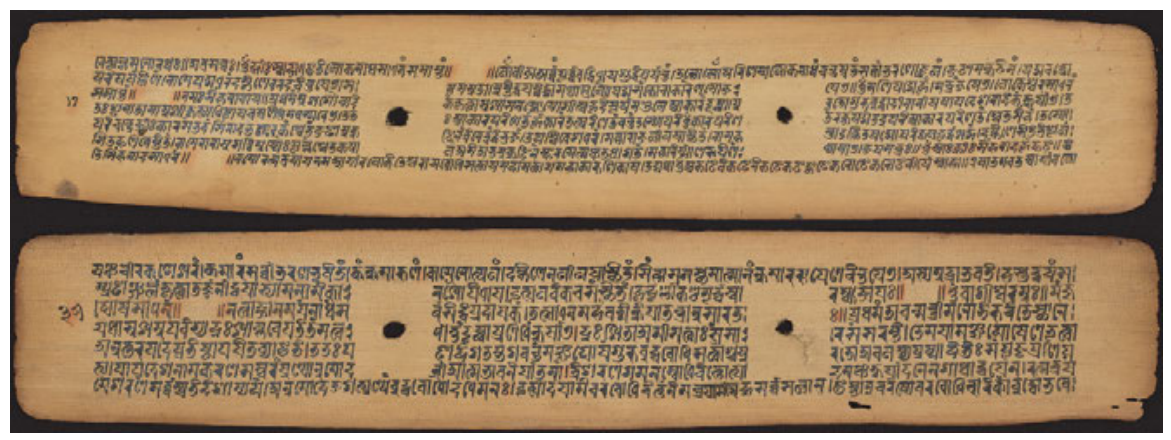

Fig. 2.4.1-XXI: Overall layout, fols. 17v, 35v @ CUL

$\mathbf{T S}_{2}$

$\mathrm{TS}_{2}$ has two string-holes per folio, each with six lines. The sample numbers of akșaras per line are 63 (9r1), 63 (22v1), 62 (50v1). The text has not been divided into text-sections on the folio. Only a square-shaped free space has been left around the left and right string-holes on each folio and on both sides, the square shaped area is four text-lines in height on the folio. The uppermost and lowermost lines run across the whole folio. Below is the overall layout of the manuscript: 


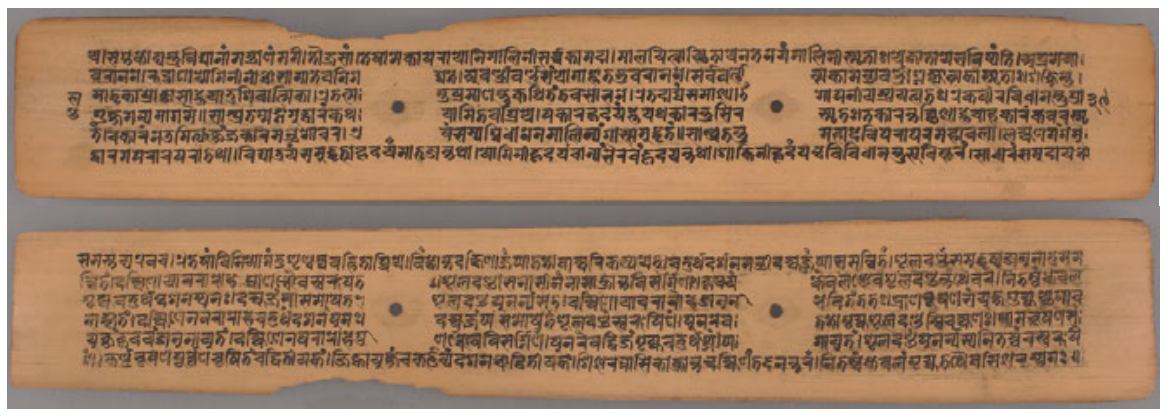

Fig. 2.4.1-XXII: Overall layout, fols. 39v, 40r @ NAK

\subsubsection{Layout in Nepalese manuscripts - Preliminary conclusions}

All $9^{\text {th }}$ c. Nepalese manuscripts ( $\mathrm{SP}_{1}, \mathrm{SP}_{2}, \mathrm{SS} / \mathrm{N}$, NTS and PT) have two string-holes per folio and the text is largely divided into three text-sections.

The $10^{\text {th }}$ c. manuscripts' (KT, YY, $\mathrm{SP}_{3}, \mathrm{SP}_{4}, \mathrm{KV} / \mathrm{UVDh}$ ) text are regularly divided into two or three text-sections. KT and YY have two string-holes per folio. Part of the text in KT is divided into two text-sections and a few other parts into three. In YY the text is divided into two text-sections only. It is also important to note that in those manuscripts with two string-holes and two text-sections, the space above and below the left string-hole is left clear of text.

Manuscripts from the $9^{\text {th }} \mathrm{c}$. $\left(\mathrm{SP}_{1}, \mathrm{PT}, \mathrm{SS} / \mathrm{N}, \mathrm{SP}_{2}, \mathrm{NTS}\right)$ do not feature regularly shaped leaves. Some leaves taper strongly at the edges and some leaves are extremely curved (folios of PT, SS/N). In these cases, the leaves' shape translates into an irregular number of lines per folio and akșaras per line. However, the examples show that from the $10^{\text {th }} \mathrm{c}$. onward the size of folios becomes more regular within each manuscript. The text is also written more uniformly to a degree. Lines appear straight. The number of lines per folio does not vary much.

Only in two Nepalese manuscripts of my corpus (SS, dated 1216 CE, and TS, ca. $13^{\text {th }}$ c.) has the text not been divided into text-sections. Only a square-shaped free space has been left around both string-holes. Such a shape is obtained by leaving four to five lines of script clear (four lines in $\mathrm{TS}_{2}$, and four to five lines in SS) around the string-holes, with only the first line and the last line of the page delimiting the upper and lower borders of the square.

Leaving gaps between sentences or pādas of śloka was a frequent feature both in part or entirely in most of the $9^{\text {th }}$ c. manuscripts (e.g. $\mathrm{SP}_{1}, \mathrm{SP}_{2}, \mathrm{NTS}, \mathrm{SS} / \mathrm{N}$ ) (see section 4.2 below). At least two manuscripts contain puranic texts (i.e. $\mathrm{SP}_{1}, \mathrm{SP}_{2}$ from $9^{\text {th }}$ c.) and one manuscript contains an epic text (i.e. $\mathrm{HV}_{1}$ from $11^{\text {th }} \mathrm{c}$.), ślokas have 
been divided using gaps in each text-sections. Vertical ruling lines have been used in manuscripts (e.g. VDh, SDhPS) on occasion.

\subsubsection{Examples of layout in East Indian manuscripts}

In the East Indian manuscripts group, of this study, I have largely analysed twelve manuscripts. Nine of them are purported to originate from present-day area of Bihar (possibly from Vikramaśila), ${ }^{119}$ the other three manuscripts from what today is the area of Bengal (PR from Bengal according to its colophon), or a nearby area. Firstly, the overall layout of each manuscript of this group has been presented in its possible chronological order, though none have been dated precisely (except PR) after which they are summed up by a few preliminary conclusions and notes on how some specific phenomena in the layout of this region's manuscripts indicating how the layout may be differentiated from the overall layout of the manuscripts from the other regions of my corpus (i.e. the layout of Nepalese and West Indian manuscripts).

\section{PR}

PR has two string-holes per folio, each with five lines (except six lines on 69v, 70r). The sample numbers of akșaras per line are 106 (28v2), 110 (35v3), 110 (50v5). The text has been divided into three text-sections on each folio. ${ }^{120}$ Each text-section has been demarcated by vertical ruling-lines on the folio. The lines are quite straight. No gaps can be found between sentences or verses on the folio (concerning precise measurements of the script and text-sections, etc., see the Cambridge online catalogue entry). The overall layout of the manuscript can be seen in Fig. 2.4.2-I.

119 Vikramaśilla was one of the important Buddhist monasteries in present-day Bihar which for various historical reasons is thought to have been destroyed around $12^{\text {th }} \mathrm{c}$. On Vikramaśila and its downfall, see Sanderson 2009, 89; Delhey et al. 2015, 121. Some of the manuscripts of this group have also been studied in Delhey 2015, 3-24 and in Delhey et al. 2015, 119-152 with regard to the composition of the material.

120 Miniatures of Buddhas, goddesses, yoginis and a stūpa can be found in the centre part of text-sections on 1v, 2r, 19v, 20r, 45v, 46r, 64v, 65r, 66v, 67r, 69v, 70r. 


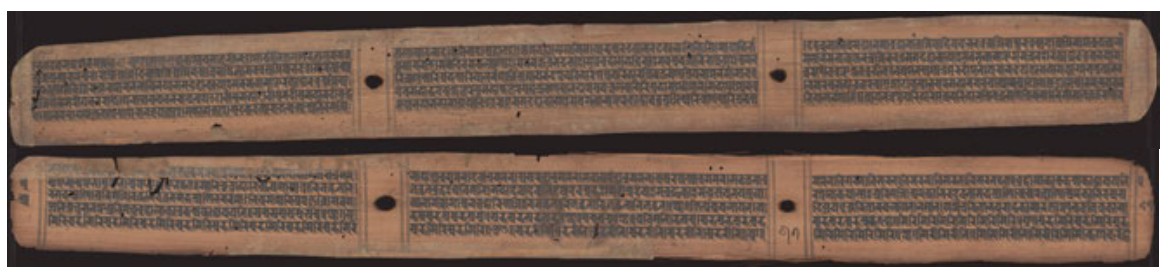

Fig. 2.4.2-I: Overall layout, fols. 26r, 67v @C CUL

\section{AAA}

AAĀ presents two string-holes per folio, each with seven lines (except six lines on 34r, 59rv-60rv, 120rv-122rv, 134rv, 135r and eight lines on 143rv). The sample numbers of akșaras per line are 125 (20v1), 116 (20v4), 127 (20v7). The folios are even and standardised. Ample free space has been left on the margins. The lines are quite regular and the text appears carefully justified. The text has not been divided into text-sections on the folio. Around both string-holes square-shaped free areas can be seen on each folio. Three lines have been left clear around both string-holes in height on each folio (except four lines on $34 \mathrm{r}$ and two lines on 59rv-60rv, 120rv-122rv, 134rv, 135r). The uppermost and lowermost two lines run across the whole folio. Figure-numerical foliation can be found on the lefthand margin on the verso. The use of space-fillers cannot be found in the manuscript. The overall layout in the manuscript can be seen as follows.

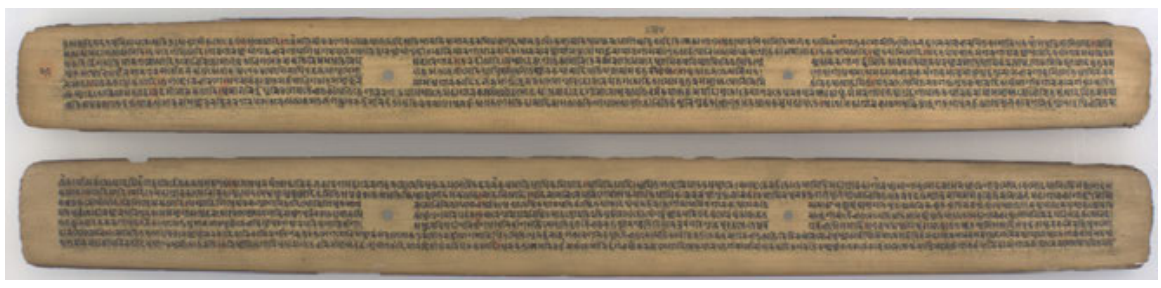

Fig. 2.4.2-II: Overall layout, fols. 35v, 36r @ NAK

\section{GV}

GV contains two string-holes per folio, each with seven lines. The sample numbers of akșaras per line are 123 (2v1), 107 (2v4), 114 (2v7). The shape of the folios is standardised and ample free space has been left on the margins. The text has not been divided into text-sections on the folio. Around both string-holes 
square-shaped free areas can be found on each folio. Three lines have been left clear of text around both string-holes on the folio. The uppermost and lowermost two lines run across the whole folio. Figure-numerical foliations can be found on the left and right-hand margins on the verso. No space-fillers can be found in the manuscript. The overall layout of the manuscript can be seen in Fig. 2.4.2-III.

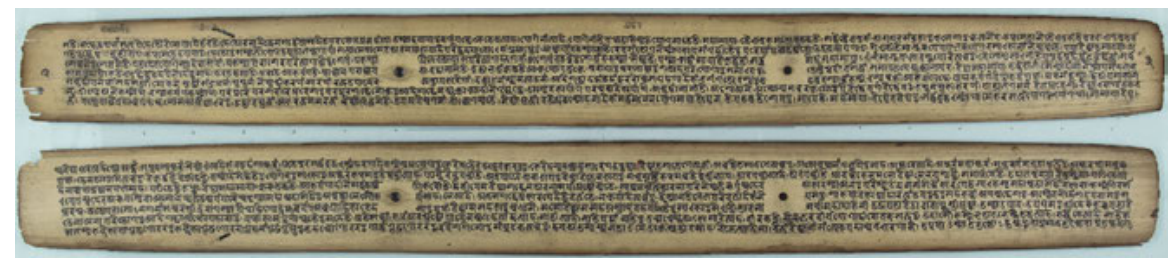

Fig. 2.4.2-III: Overall layout, fols. 3v, 4r @ KL

\section{HAP}

HAP has two string-holes per folio, each with seven lines (except for the first folio (1r) and last one (10rv). On $1 \mathrm{r}$ there are three and a half lines and the text seems to have been written by the same hand later. There are two and over a half line on 10r and the text ends there. There is just one line on 10v.). The sample numbers of akșaras per line are 143 (3v1), 126 (3v4), 133 (3v7). Folios are standardised and ample free space has been left on the margins. Lines are straight. The text has not been divided into text-sections on the folio. Around both string-holes square-shaped free areas have been left on each folio. Three lines are left clear around both string-holes on the folio. The uppermost and lowermost two lines run across the whole folio. Figure-numerical foliations can be found on the left and right-hand margins on the verso. There are no spacefillers in the manuscript. The overall layout in the manuscript can be seen in Fig. 2.4.2-IV. 


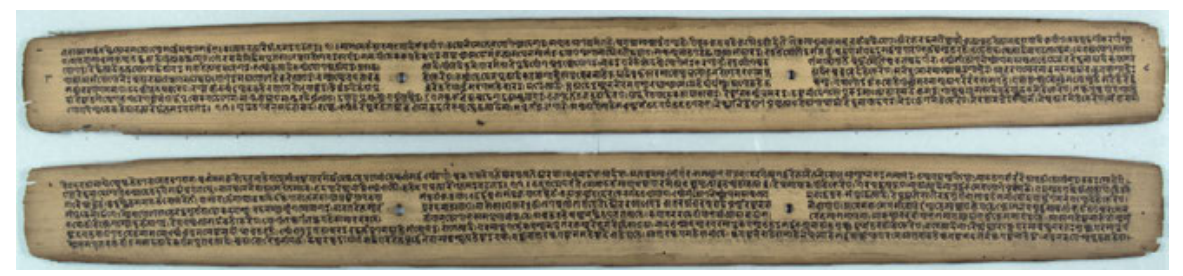

Fig. 2.4.2-IV: Overall layout, fols. 8v, 9r @ $\mathrm{KL}$

LTT

LTT has two string-holes per folio, each with seven lines. The sample numbers of akșaras per line are 139 (5v1), 130 (5v4), 135 (5v7). The text has not been divided into text-sections on the folio. The folios are standardised and ample free space has been left on the margins. Around both string-holes square-shaped free spaces are left clear on each folio. Three lines have been left clear around both string-holes on the folio. The two uppermost and lowermost lines run across the whole folio. Figure-numerical foliations can be found on the left and right-hand margins on the verso. Space-fillers cannot be found in the manuscript. Below is the overall layout of the manuscript:

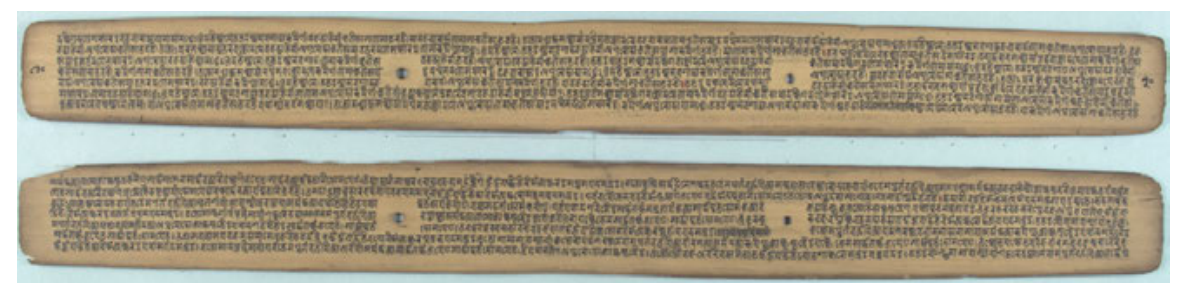

Fig. 2.4.2-V: Overall layout, fols. 20v, 21r (C KL

\section{STT}

STT has two string-holes per folio, each with seven lines. The sample numbers of akșaras per line are 136 (7v1), 118 (7v4), 124 (7v7). The text has not been divided into text-sections on the folio. Around both string-holes square-shaped free spaces have been left clear on each folio. Three lines are left clear around both string-holes on the folio (except $1 \mathrm{v}$ on which around the right string-hole just two lines are left clear in height). The two uppermost and lowermost lines run across the whole folio (except the right string-hole space on 1v). On 2r6, 2r7 a 
few mantras can be found written in kūțākșara. ${ }^{121}$ Figure-numerical foliations can be found on the left and right-hand margins on the verso. Space-fillers have not been used in the manuscript. Below is the overall layout of the manuscript:

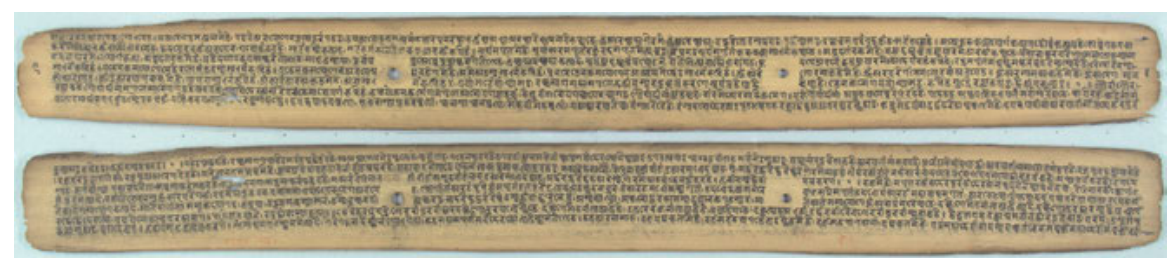

Fig. 2.4.2-VI: Overall layout, fols. 4v, $5 \mathrm{r} \odot \mathrm{KL}$

\section{DQVPT}

DVPT contains two string-holes per folio, each with seven lines (except the last folio $8 \mathrm{v}$ on which only three lines can be found). The sample numbers of akșaras per line are $121(2 \mathrm{v} 1), 111(2 \mathrm{v} 4), 118(2 \mathrm{v} 7)$. Ample free space has been left on the margins. The lines are regular and the text has been carefully justified. The text has not been divided into text-sections on the folio. Around both stringholes square-shaped free spaces can be seen on each folio. Three lines are left clear around both string-holes in height on each folio. The uppermost and lowermost two lines run across the whole folio. Figure-numerical foliations can be found on the left and right-hand margins on the verso. Space-fillers cannot be found in the manuscript. The overall layout in the manuscript can be seen in Fig. 2.4.2-VII.

121 Sometimes understood to be 'monogram' or 'mantra monogram', which, literally means, 'heap syllable(s)' (see Hartmann 1998, 38). This label indicates special sets of visual configurations, in which syllables and syllable-like characters used in mantras or mantra-like elements are written underneath one another, making them all look closely intertwined. See also Śākya 1973, 37-38; Rajbanshi 1974, 104-105. 


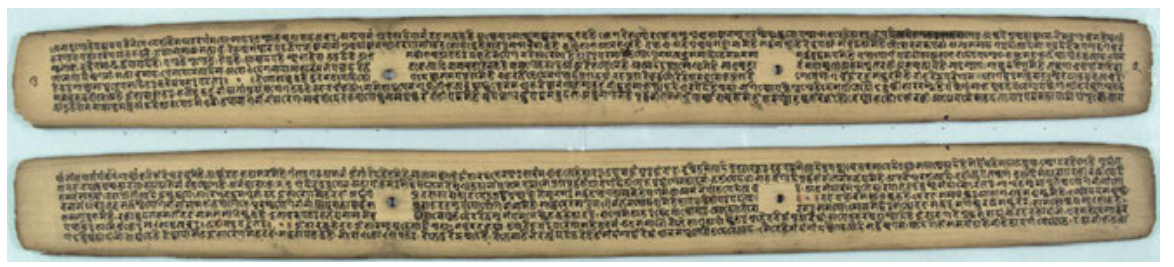

Fig. 2.4.2-VII: Overall layout, fols. 2v, 3r @ KL

\section{AP}

AP has two string-holes per folio, each with seven lines (except for the last folio 28r). The sample numbers of akșaras per line are 142 (9v1), 138 (9v4), 131 (9v7). Ample free space has been left on the margins. The lines are very regular and the text has been carefully justified. The text has not been divided into textsections on the folio. Around both string-holes square-shaped free areas have been left clear on each folio. Three lines have been cleared around both stringholes in height on the folio. The uppermost and lowermost two lines run across the whole folio. Figure-numerical foliation can be found on the left-hand margin on the verso. Space-fillers cannot be found in the manuscript. The overall layout in the manuscript can be seen in Fig. 2.4.2-VIII.

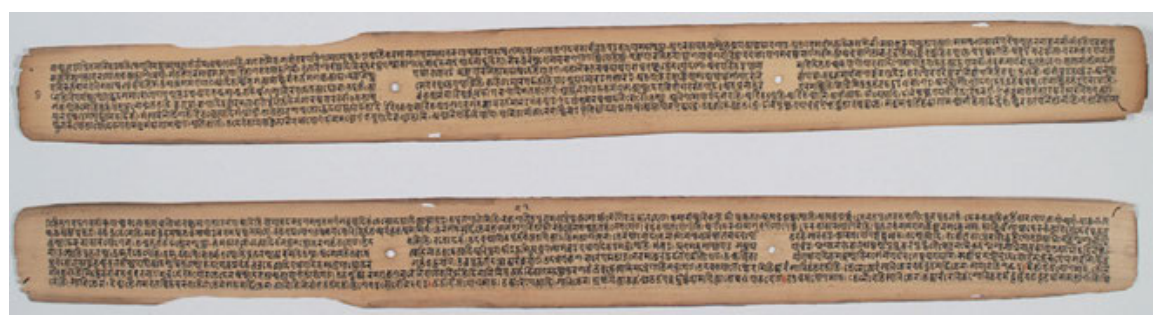

Fig. 2.4.2-VIII: Overall layout, fols. 5v, $6 \mathrm{r}$ @ NAK

\section{CPN}

CPN presents two string-holes per folio, each with seven lines (except last folio on which only six lines can be found). The sample numbers of akșaras per line are 127 (4v1), 116 (4v4), 123 (4v7). Ample free space has been left on the margins. Lines are regular and the text has been carefully justified. The text has not been divided into text-sections on the folio. Around both string-holes square-shaped free areas can be seen on each folio. Three lines have been left clear around 
both string-holes in height of the folio. The two uppermost and lowermost lines run across the whole folio. A few mantras are written in kūțākșara on 8v3, 9r7, 10v5, 14v5, 14v6, 41v7, 52r4. Figure-numerical foliations can be found on the left and right-hand margins on the verso. Space-fillers cannot be found in the manuscript. The overall layout in the manuscript can be seen in Fig. 2.4.2-IX.

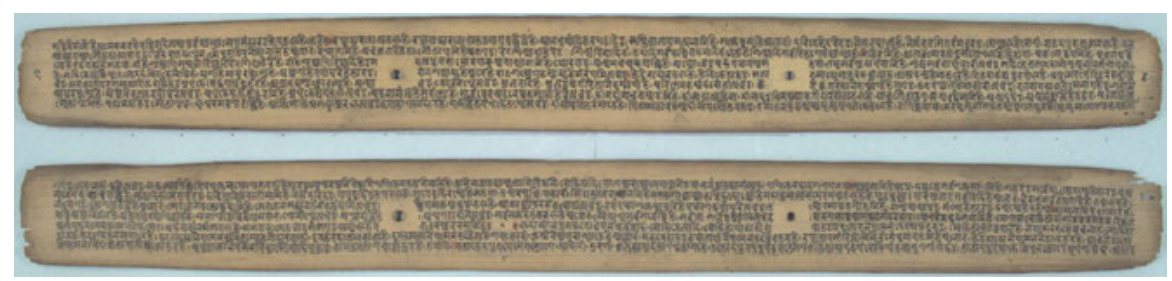

Fig. 2.4.2-IX: Overall layout, fols. 4v, $5 \mathrm{r} \subset \mathrm{KL}$

\section{HP}

HP has two string-holes per folio, each with seven lines (except last folio 23r on which only three lines can be found). The sample numbers of akșaras per line are 153 (16v1), 133 (16v4), 142 (16v7). Ample free space has been left clear on the margins. The lines are very regular and the text has been carefully arranged. The text has not been divided into text-sections on the folio. Around both stringholes square-shaped free areas can be seen on each folio. Three lines have been left clear around both string-holes in height on the folio. The uppermost and lowermost two lines run across the whole folio. Figure-numerical foliations can be found on the left and right-hand margins on the verso. Space-fillers cannot be found in the manuscript. Below is the overall layout of the manuscript:

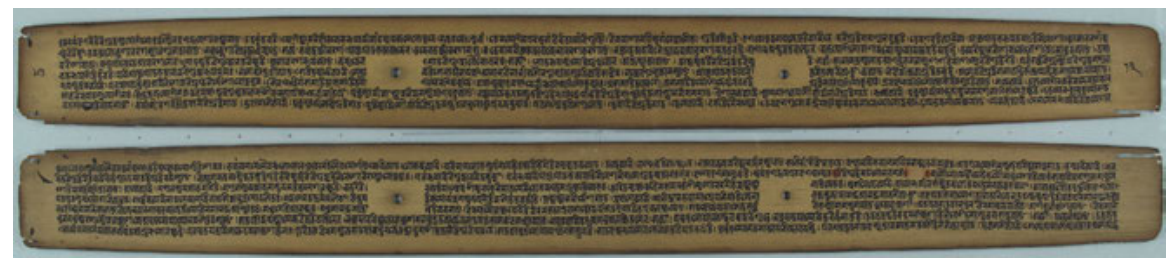

Fig. 2.4.2-X: Overall layout, fols. $13 \mathrm{v}, 14 \mathrm{r}$ (C) KL 


\section{HTT}

HTT contains one string-hole per folio, each with six lines (except seven lines on 56v). The sample numbers of akșaras per line are 54 (4v4), 59 (4v6). The text has not been divided into text-sections on the folio. Just two lines are cleared around the string-hole space. The uppermost and lowermost two lines run across the whole folio (except on folio 56v on which the lowermost three lines run across the whole folio). The text has been written mostly in cursive. No space-fillers can be found in the manuscript. The overall layout in the manuscript can be seen in Fig. 2.4.2-XI.

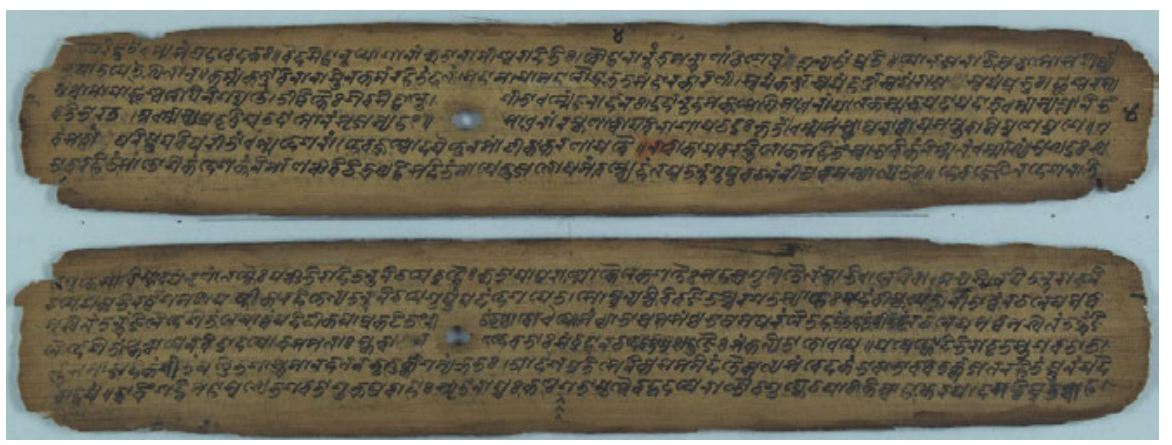

Fig. 2.4.2-XI: Overall layout, fols. $4 \mathrm{v}, 5 \mathrm{r}$ (C) $\mathrm{KL}$

\section{AT}

AT has one string-hole per folio, each with five lines (except six lines on a few folios). The sample numbers of akșaras per line are 52 (15?v1), 49 (15?v3) 47 (15?v6). The text has not been divided into text-sections on the folio. A part of the text is written in cursive. The overall layout can be seen in Fig. 2.4.2-XII. 


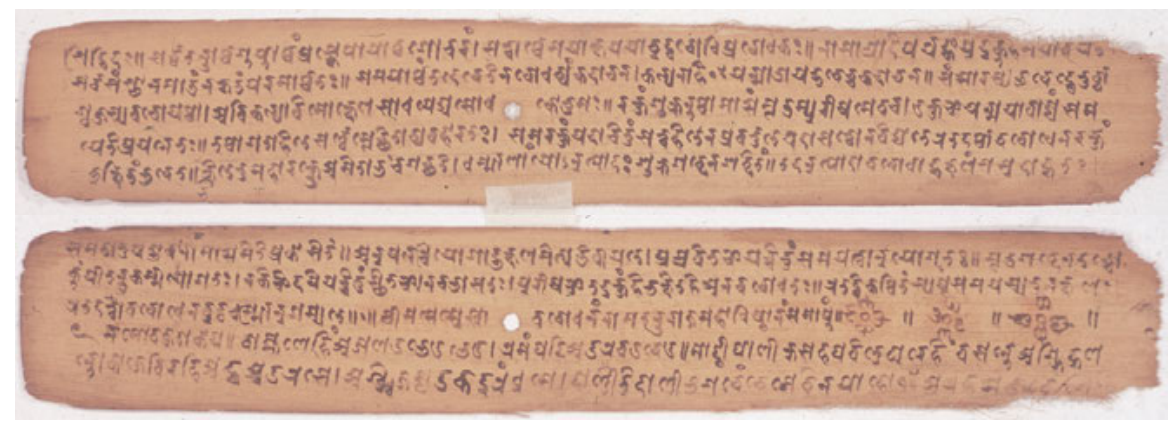

Fig. 2.4.2-XII: Overall layout, fols.? @ General Library, University of Tokyo

The folios of the manuscripts which are supposed to have originated from Vikramaśila (GV, HAP, LTṬ, STṬ, ḌPTT, AP, CPN, HP) ${ }^{122}$ appear extremely uniform in shape. The folios are long and have almost identical size (e.g. length of manuscripts is $55-57 \mathrm{~cm}$ and height $5-6 \mathrm{~cm}^{123}$ ) and folios do not taper (so much) on the edges or they are not curved..$^{124}$

\subsubsection{Layout in East Indian manuscripts - Preliminary conclusions}

All East Indian manuscripts contain square-shaped free space around both string-holes on the folio (except in HTT and AT, in which just one or two lines are left clear around the string-holes and the left area is not a square-shaped box, and PR in which lines are left clear above and below both string-holes of

122 In the manuscript of the Pāramitāsamāsa (NAK 5/145 / NGMPP A 39/9) which might also have originated from the same area (depending on the palaeography and occurrence of the symbols), there are seven lines per folio and three lines are cleared around both string-holes on the folio. The following manuscripts have an almost identical layout and palaeographical similarities, e.g. the manuscript of the Dākinivajrapañjarapañjikā (NAK 5/20 / NGMPP A 47/17(1)) (preserved in Nepal), the manuscript of the Kalyānakāmadhenuvivarana (NAK 5/20 / NGMPP A 47/17(2)) (folio 4 is kept in Nepal and all other folios are preserved in Tibet); the manuscript of the Trisamayarājatantrațikā (NAK 5/20 / NGMPP A 47/17(3)) (folios 2, 3, 5-9, 11 15, 18, 19 are preserved in Nepal and folio 4 is found in Tibet) (on the identification of the corpus of many of these manuscripts by Harunaga Isaacson, see Delhey et al. 2015, footnote 13); the manuscript of the Vimssatividhi (Tucci_MT 34 EE); the manuscript of the Bhikșuni-Vinaya, see Roth 1970, plate 9A.1-6; the manuscript of the Smrrtyupasthānasūtra; the manuscript of the Jñānaśrīmitranibandhāvalī (18 A_Sānkrtyāyana).

123 The size is based on the measurements of the catalogue cards of the NGMPP.

124 See also Delhey et al. 2015. 
the folios). In most cases three lines have been left clear around both stringholes. The square shape is obtained with the first two lines and the last two lines of each page demarcating the upper and lower sides of the free space around the string holes. Although not directly related to the layout in the manuscripts a relatively important point is worthy of mention - many of the manuscripts of this group contain new covers, painted yellow (GV, HAP, LTT, STT, DVPT, CPN, HP, HTT ). Except for the size of covers of HTT, the size and the shape of manuscript covers (GV, HAP, LTT, STT , DVPT, CPN, HP) are identical.

Ruling-lines are not found in the manuscripts of this region discussed in my corpus, except for PR in which they are used to demarcate text-sections. The number of lines should also be noted. In most manuscripts there are seven lines per folio, each of which is fairly straight. Both margins are carefully arranged so there are no space-fillers in any of the manuscripts, and a space of remarkably regular size is left blank on both left and right sides of the folio. Another conspicuous feature is also worthy of mention. Most of the manuscripts of this group contain figure-numerical foliations on both the left and right-hand margins (namely, GV, HAP, LTT, STT, DVPT, AP, CPN, HP).

Approximately the same number of akșaras per line is found in many manuscripts of this group e.g. the average number of akșaras: 116-127 in AAĀ, 114123 in GV, 126-133 in HAP, 130-139 in LTT, 118-136 in STT, 111-121 in DVPT, 131-142 in AP, 116-127 in CPN, 133-152 in HP.

A symbol that looks like a 'siddham' can be found at the end of the chapter or text in many manuscripts of this group (see section 3.4, type no. 45 and section 3.5.2 below). Their shape is near identical, and may perhaps be used to trace most of these manuscripts back to the same geographical area.

Finally, a feature concerning the genre of the texts found in the manuscripts of this group is worth noting: all texts have a Buddhist affiliation. Ten contain commentaries on Buddhist tantric texts (GV, HAP, LTT, STṬ, DVPṬ, AP, CPN, HP, HTT and AT). ${ }^{125}$ PR contains a dhāraṇi and AAĀ contains a commentary to a Buddhist mahāyānic text.

125 It is also important to mention here that we find some characters which look Tibetan in at least three manuscripts of this group, namely, in GV, LTT and CPN. In all manuscripts they appear on $1 \mathrm{r}$ but aside from that the folios are fairly blank. In the case of GV we can see a short text part (in two lines) in the middle on the space between left and right string-holes on $1 \mathrm{r}$. According to the appearance of characters it seems to be written in Tibetan script, though it appears that there was an attempt to deliberately erase parts of characters and a horizontal line in the script area is still visible in the first line of the text part that was perhaps used for the deletion. Furthermore, in LTT on 1r, which is also blank (except for a verse that appears in the middle on the space between left and right string-holes), we find under the verse a dark spot of 


\subsubsection{Examples of layout in West Indian manuscripts}

I have examined seven manuscripts from West India. One manuscript contains a commentary of the Haravijayamahākārya an epic poem. The other manuscripts largely contain texts (both mūla ('root') texts and commentaries) related to the Jaina tradition. The manuscripts can be dated $12^{\text {th }}$ to $13^{\text {th }}$ c. approximately. The manuscripts will be presented in (probable) chronological order, outlining their overall layout and providing examples for each manuscript.

\section{TSa}

TSa presents one string-hole per folio, each with four to six lines. The sample numbers of akșaras per line are 61 (20v1), 62 (39v5), 64 (114v3). The text has been divided into two text-sections on each folio. The left text-section is narrower than the right text-section. Both text-sections are demarcated by vertical ruling-lines. A symbol can be found around the string-hole on each folio. The overall layout in the manuscript can be seen as follows.
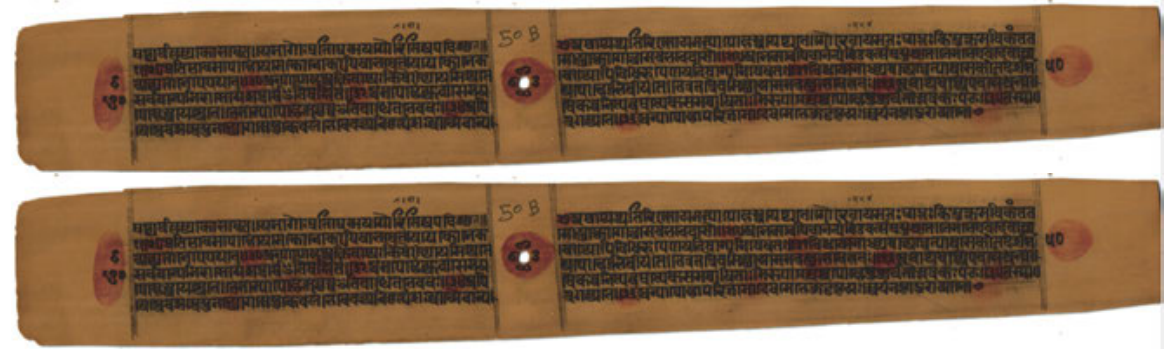

Fig. 2.4.3-I: Overall layout, fols. 50v, 84v @ Jinabhadrasūri Jñāna Bhạ̣ḍāra, Jaisalmer

an ink-like element and parts of some curved lines at the bottom of the dark spot are still visible. It appears also that the line here was probably written in Tibetan script which someone intentionally tried to erase. As the spot appears to some extent in the same place on the folio like in GV and CPN (i.e. between left and right string-holes), we can assume that the writing was probably in Tibetan script as well. Similarly, in CPN on 1r, which is blank, we find a twoline short text portion in the middle on the space between left and right string-holes. It is also written in Tibetan script. The second line seems to have been erased intentionally. A horizontal line in the script area can be seen, which here too, was most probably used to mark the deletion. These examples of deletion may suggest how we are to think of the user of the manuscripts. It is likely at least to some extent that these manuscripts were in the hands of a reader of the Tibetan language or knower of Tibetan writing. 


\section{TSPV}

TSPV has two string-holes per folio, each with three to nine lines. The sample numbers of akșaras per line are 106 (18v2), 144 (37v5), 117 (144?v4), 118 (312v1). The text has been divided into three text-sections. All three text-sections are demarcated by vertical ruling-lines. Symbols can be found around both stringholes on each folio. At least four scribes may have worked on the manuscript production. ${ }^{126}$ Above is the overall layout of the manuscript.

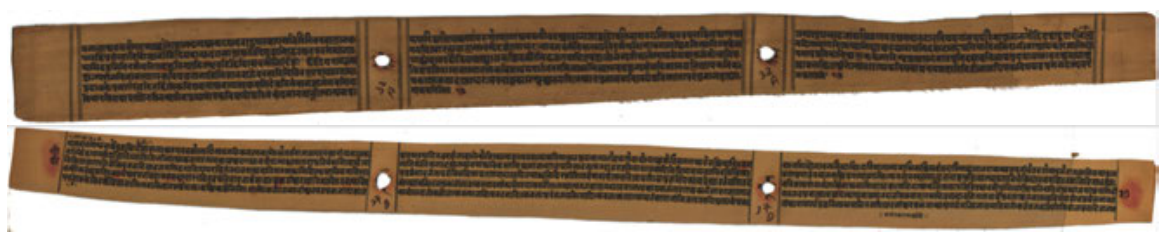

Fig. 2.4.3-II: Overall layout, fols. 32v, 37v @ Jinabhadrasūri Jñāna Bhaṇḍāra, Jaisalmer

\section{HVM}

HVM contains two string-holes per folio, each with four to seven lines. The sample numbers of akșaras per line are 179 (1v1), 189 (21v4), 96 (46v6). The text has been divided into three text-sections. All three text-sections are demarcated by vertical ruling-lines. Symbols can be found around both string-holes on each folio (see section 3.6.1 below). Both symbols around the string-holes seem to have been highlighted (see section 5.1). Furthermore, both foliations (letternumeral on the left-hand and figura-numeral on the right-hand margin) have also been highlighted. The overall layout in the manuscript can be seen as follows.

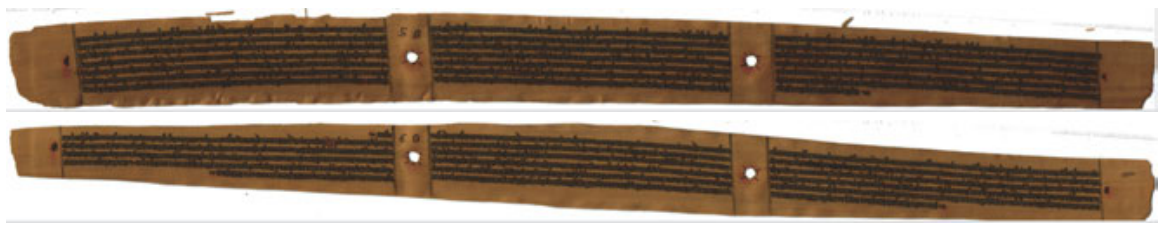

Fig. 2.4.3-III: Overall layout, fols. 5v, 6v @ Jinabhadrasūri Jñāna Bhaṇḍāra, Jaisalmer

126 This is discussed in detail in section 3.9.4 below. 


\section{PV}

PV has one string-hole per folio, each with four to five lines. The sample numbers of akșaras per line are 58 (18v1), 55 (74r1). The text has been divided into two textsections on each folio. The left text-section is narrower than the right. Both textsections are delimited by a set of double vertical ruling-lines. There is a symbol around the string-hole on each folio. A few tables and diagrams with akșaras and figure-numerals are found in the manuscript (e.g. $87 \mathrm{r}, 89 \mathrm{v}, 90 \mathrm{r}$ and on a few last folios). The overall layout in the manuscript can be seen in Fig. 2.4.3-IV.

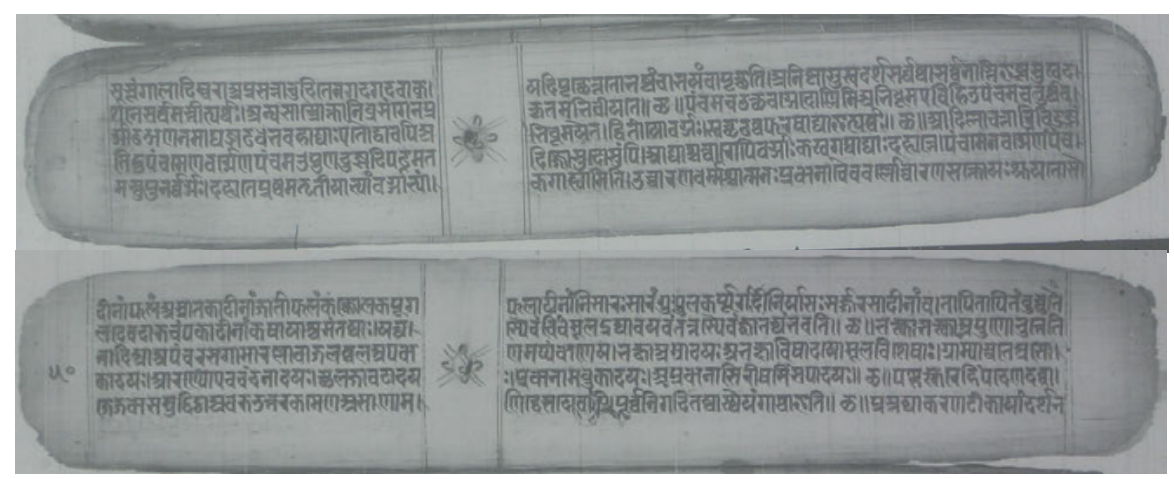

Fig. 2.4.3-IV: Overall layout, fols. 28r, 50v @ NAK

$\mathrm{JKS} / \mathrm{C}$

JKS/C presents one string-hole per folio, each with two to eight lines. The sample numbers of akșaras per line are 47 (20v1), 53 (22v1). The text has been divided into two text-sections on each folio. The left text-section is narrower than the right text-section. Both text-sections are demarcated by vertical ruling-lines. Furthermore, both foliations (letter and figure-numerals) have been highlighted. A symbol can be found around the string-hole on each folio and it appears highlighted. The overall layout in the manuscript can be seen in Fig. 2.4.3-V. 


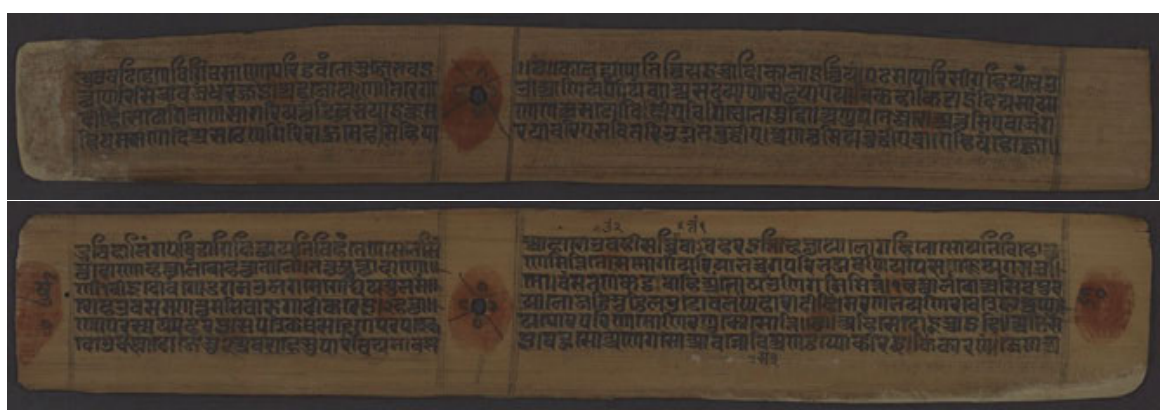

Fig. 2.4.3-V: Overall layout, fols. 23r, 60v (C British Library Board, London

\section{TUS}

TUS contains one string-hole per folio, each with two to eight lines. The sample numbers of akșaras per line are 50 (33v3), 57 (112v2). The text has been divided into two text-sections on the folio. The left text-section is narrower than the right text-section. Both text-sections are demarcated by vertical ruling-lines. A symbol can be found around string-hole on each folio and they appear highlighted. Both foliations (letter and figure-numerals) have also been highlighted. The overall layout in the manuscript can be seen in Fig. 2.4.3-VI.

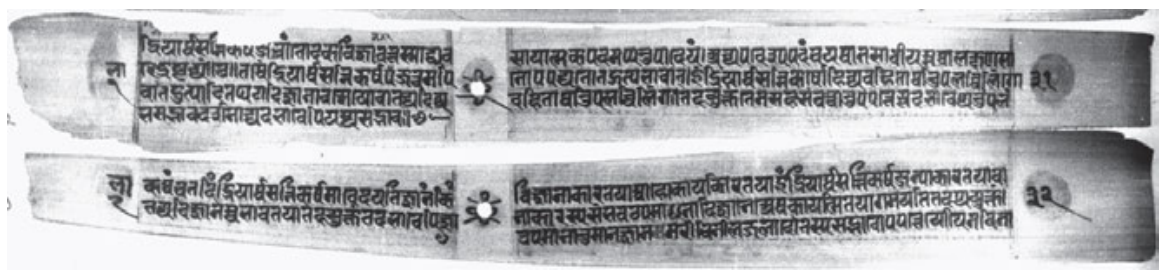

Fig. 2.4.3-VI: Overall layout, fols. 31v, 32v (C Hemacandrācārya Jaina Jñānamandira, Patan 


\section{BCV}

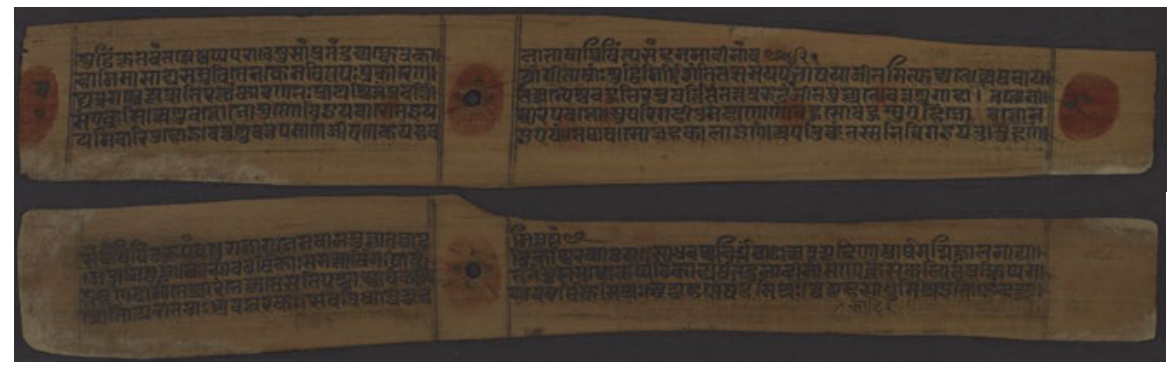

Fig. 2.4.3-VII: Overall layout, fols. 20v, 42r @ British Library Board, London

BCV presents one string-hole per folio, each with three to seven lines. The sample numbers of akșaras per line are 48 (11v1), 45 (70v1). The text has been divided into two text-sections on each folio. The left text-section is narrower than the right textsection. Both text-sections are delimited by vertical ruling-lines. A symbol can be found around the string-hole on each folio and they appear highlighted. Both foliations (letter and figure-numerals) have also been highlighted. The overall layout in the manuscript can be seen in Fig. 2.4.3-VII.

\subsubsection{Layout in West Indian manuscripts - Preliminary conclusions}

All manuscripts from this area contain vertical ruling-lines ${ }^{127}$ on the folio and they demarcate each text-section. Although it is difficult to ascertain when and where the ruling-lines first appeared in Indic manuscripts, it is clear they have become a common scribal practice in manuscripts from West India.

Almost no gaps can be found either in prose passages or between verses. The number of lines per folio vary extremely, even within a single manuscript (e.g. HVM has four to seven lines, JKS/C two to eight lines, TSa four to six lines, TUS two to five lines, and BCV three to seven lines). ${ }^{128}$ This latter feature is closely related to the shape of the leaf.

127 On the use of ruling-lines, see also Thaker 2002, 143.

128 See also further manuscripts from the same region, e.g., in the manuscript of the Udbhațakāvyālañkāralaghuvṛtti (VS 1160 / 1103 CE) (Jinabhadrasūri Grantha Bhaṇụāra, Jaisalmer, no. 329) there are three to five lines per page; in the manuscript of the Jayadevachandah Sāstra (VS 1190 / 1133 CE) (Jinabhadrasūri Grantha Bhaṇḍāra, Jaisalmer, no. 314/1) two to six lines per 
According to the number of string-holes, one can find two or three textsections on the folio (e.g. two text-sections can be found in TSa, PV, JKS/C, TUS and BCV and three text-sections in HVM and TSPV). Furthermore, all manuscripts contain simple symbols around the string-hole of each folio (see section 3.6.1 for more detail below). In all manuscripts the space surrounding the stringholes has been left clear from top to bottom. Regarding those with only one stringhole per folio, the hole appears at a distance of slightly more than a quarter of the whole folio starting from the left edge. As a result, the left text-section is always narrower than the right text-section (e.g. the text-sections in TSa, PV, JKS/C, TUS and BCV). A large free space often features on the left and right margins on the folio.

Foliation can be found on both margins in all the West Indian manuscripts of the corpus - letter-numerals on the left margin and figure-numerals on the right margin (except in PV where only figure-numerals can be found on the left margin) and both foliations are highlighted (see section 5.1 for more details below).

\subsubsection{Layout - Overall conclusions}

To provide easy reference for the readers, I will place the observations found above, on the general features of the manuscripts of the three areas, under consideration.

(a) Nepalese manuscripts exhibit a variety of layouts. They may have two or three text-sections per page or no text-sections at all. Ruling-lines and gaps (either between sentences or verse lines) occur occasionally. In addition, at times ślokas are arranged within text-sections by means of gaps. It is also important to note that two of the manuscripts with the sloka division by gaps within text-sections contain puranic texts (i.e. $\mathrm{SP}_{1}, \mathrm{SP}_{2}$ ) and the other one contains

page; in the manuscript of the Sūtrakṛtāngasūtravrtti (VS 1200 / 1143 CE) (Jinabhadrasūri Grantha Bhanḍāra, Jaisalmer, no. 4) three to six lines per page; in the manuscript of the Kalpalatāiviveka (Kalpapallavaśeșa) (VS 1205 / 1148 CE) (Jinabhadrasūri Grantha Bhaṇḍāra, Jaisalmer, no. 317) two to seven lines per page; in the manuscript of the Upadeśapadaprakaraṇalaghuțīkā (VS 1212 / 1155 CE) (Jinabhadrasūri Grantha Bhaṇ̣āra, Jaisalmer, no. 214/1) three to six lines per page; in the manuscript of the Șad̄a ấyakasūtravrtti (VS 1298 / 1241 CE) (Jinabhadrasūri Grantha Bhaṇ̣āra, Jaisalmer, no. 136/1) four to six lines per page; in the manuscript of the Sthānāngasūtravṛtti (VS 1300 / 1295 CE) (Jinabhadrasūri Grantha Bhaṇḍara, Jaisalmer, no. 6) four to seven lines per page; in the manuscript of the Praśnavyākaraṇadaśāñgasūtravṛtti (VS 1300 / 1295 CE) (Jinabhadrasūri Grantha Bhaṇḍāra, Jaisalmer, no. 23/3) two to four line per page. 
an epic text (i.e. $\mathrm{HV}_{1}$ ). One could argue that the texts written largely in one metre - as is the case with the Purānas and epic texts, which are composed almost exclusively in ślokas - fit the text-section layout suitably.

(b) The layout of manuscripts from East India, in particular those purported to be from Vikramaśīla, is very carefully organised. Most manuscripts contain seven lines per folio (except for PR, HTT and AT), and are usually written in a rather straight manner. No text-sections are found (with one exception in the corpus; the Bengali PR where the text is divided into three text-sections and each text-section demarcated by vertical ruling-lines). In most of the manuscripts square-shaped free space appears around both string-holes. For the free space around the string-holes, three lines have been left clear in height on the folio. There is ample free space on the margins of the folio. Clear visible gaps like those between sentences or ślokas in some Nepalese manuscripts are not found on the folio in East Indian manuscripts. In terms of the text genre, all manuscripts contain Buddhist (commentary) texts.

(c) In the West Indian manuscripts of my corpus, the text appears to be organised in two to three text-sections. While we find the use of vertical rulinglines (occasionally) as well as in some Nepalese and East Indian manuscripts, ${ }^{129}$ their use is consistent with all West Indian manuscripts of my corpus. Each textsection appears demarcated by vertical ruling-lines on the folio. Large margins can also be found in West Indian manuscripts. Foliations (both letter and figurenumerals) appear highlighted (see section 5.1 for more details). The symbols around the string-holes often appear highlighted. No use of blank spaces can be found at the end of the chapters or text in the manuscripts.

129 For example, in VDh, ruling-lines have been used partly. Furthermore, in the manuscript containing texts of the Prajñāpāramitāstotra, Aștasāhasrikā Prajñāpāramitā and Vajradhvajaparināmanā (NS 135 / 1015 CE) (CUL Add.1643), one can also find the use of ruling-lines. Among the East Indian manuscripts, ruling-lines can be seen in the manuscript containing texts of the Prajñāpāramitā and Aștasāhasrikā Prajñāpāramitā (1070 CE) (CUL Add.1464) (see also Bendall 1883, ii and 100). 